\title{
Effect of Artificial Ageing Using Different Wood Chips on Physico-chemical, Sensory and Antimicrobial Properties of Apple Tea Wine
}

Vikas Kumar ${ }^{1,2^{*}}$

https://orcid.org/0000-0002-9593-6463

\section{Vinod Kumar Joshi ${ }^{1}$}

Narayan Singh Thakur ${ }^{1}$

https://orcid.org/0000-0002-6896-2316

\section{Nivedita Sharma ${ }^{3}$}

https://orcid.org/0000-0002-2685-0308

\section{Rakesh Kumar Gupta ${ }^{3}$}

https://orcid.org/0000-0001-6685-5691

${ }^{1}$ Dr. Yashwant Singh Parmar University of Horticulture and Forestry, Department of Food Science and Technology, Nauni, Solan (Himachal Pradesh), India. 2Punjab Agricultural University, Department of Food Science and Technology, Ludhiana, Punjab, India. ${ }^{3}$ Department of Basic Sciences, Dr. Yashwant Singh Parmar University of Horticulture and Forestry, Nauni, Solan (Himachal Pradesh), India.

Received: 2018.08.06; Accepted: 2020.02.07.

${ }^{*}$ Correspondence: Department of Food Science and Technology, Punjab Agricultural University Ludhiana, Punjab, 141004, India; Phone number: +919418653296; e-mail: vkchoprafst@rediffmail.com

\section{HIGHLIGHTS}

- To overcome the yeasty and dull flavor of freshly prepared apple tea wine, aging is required.

- Different types of wood chips (2.5 g/L) were added to the freshly prepared apple tea wine and allowed for the ageing i.e. 6 months.

- Storage intervals significantly affected all the physico-chemical attributes.

- Addition of wood chips affected titratable acidity, ethanol, higher alcohols, total phenols and amino acid.

- Apple tea wine matured with Quercus spp. wood chips for 6 months was the best with improved physico-chemical and sensory characteristics.

Abstract: Freshly prepared apple tea wine (a combination of tea extract and apple juice) is having yeasty and dull flavour, which needs to be improved to increase the acceptability of this product. Therefore, an attempt has been made for artificial ageing of apple tea wine using different wood chips to improve its physicochemical, sensory and antimicrobial attributes. Different types of wood chips (Quercus spp., Bombax spp. and Acacia spp.) were added respectively ( $2.5 \mathrm{~g} / \mathrm{L}$ to the freshly prepared apple tea wine) and allowed for 
ageing in carboys for the six months at the room temperature. The influence of each wood species on physico-chemical, sensory and antimicrobial attributes was tested upto 6 months of storage. Storage intervals significantly affected all the physico-chemical attributes (except total sugars, volatile acidity, and antioxidant activity), whereas, the addition of wood chips affected titratable acidity, ethanol, higher alcohols, total phenols, and amino acid. Cluster analysis of the physico-chemical attributes data revealed the same and showed that storage intervals exerted more effect on the physico-chemical and antimicrobial properties of the apple tea wine rather than the wood chips. The antimicrobial activity of 6 months aged wine was low as compared to the fresh wine. Among all the wood chips, apple tea wine aged with Quercus spp. possesses a significantly higher score (according to desirability) than the wine aged with other wood chips and control. In nutshell, apple tea wine matured with Quercus spp. wood chips for 6 months were the best with improved physicochemical and sensory attributes.

Keywords: Apple tea wine, artificial ageing, wood chips

\section{INTRODUCTION}

Brewing and consumption of various liquors were developed traditionally into art in ancient India, every single tribal society had a balanced and beautiful relationship with spirituous stimulants. Man's relationship with wine is as old as history and nature. For centuries, wine has been used in religious ceremonies, for recreational and medicinal purposes. It has been a part of the society, meal and social gathering [1]. Wines have always been considered as safe and healthy drinks, besides an important adjunct to the diet [2]. The wine possesses different types of health effects due to the presence of phenolics and alcohol in wine, which protects the human body from free radical attacks and increases HDL level in the body [3].

With the advancement of time and upliftment of the economic status of people, the interest in health and wellbeing in life has been considerably raised which in turn increased the usage of natural materials to improve the nutritional quality of the diet [4]. Phenolic compounds play an important role in enology [as they are responsible for the colour and flavour of red and white wines] as well as human health [5]. Besides being bactericidal, these are responsible for the 'French paradox' with antioxidants and vitamins that apparently protect consumers from cardiovascular diseases [6]. However, besides the red wines, wine from non-grape fruits such as apple, pear etc. has the big issues of the low polyphenolics content and ultimately affecting the phytochemical potential of the wine. So, the same problems have been already taken care in our earlier attempts while preparing apple tea wine using different types of tea, their respective concentrations along with different types of fermentations i.e. natural and inoculated and their effect on the phytochemicals as well as antimicrobial activity [4,6], different types of additives and their effect on the quality attributes of apple tea wine [8].

Newly fermented wine possesses dull, yeasty and raw taste. Therefore, aging is highly required in wine to develop good appearance, mouthfeel, and flavour. Among the numerous again aging methods, the utilization of wood barrels and chips is the old and traditional wine making practice, which imparts positive effects on the organoleptic and chemical quality attributes of wine [9]. The role of wood in wine aging is to transfer volatile aromatic compounds and astringency-related phenolics to wine, to improve the intensity and complexity of wine flavour and aroma $[5,10]$. The selection of the woods for preparation of wood chips or barrels depends on its origin, physical characteristics of wood [grain, porosity, permeability] and it's chemical composition [polyphenols, tannins, volatile compounds] which can influence the composition of wine during the aging process[5]. The wood of various species of white oak, red wood, Acacia, pine, chestnut, and eucalyptus have been frequently used to make barrels [11]. Aging of wines in wood barrels requires long periods and has been found to be very costly. This problem has been overcome by artificial aging using wood chips which are prepared using traditional methods in cooperage and subjecting them to boiling in water and toasting as documented by Bozalongo and coauthors [12]. Besides that, wood chips, however, have a greater and faster effect on wine than barrels or other methods of maturation [13]. The woods of Quercus, Albizia, Bombax, Toona, Celtice, and Salix chips have been used successfully in the maturation of wines and significant changes in tannins, methanol, and sensory quality have been observed [14].

Until today to our knowledge, a lot of attempts have been made for the preparation and maturation of tea wine and other fruit wine, but especially the artificial aging of the apple tea wine using different wood chips is still lacking and not documented until date. Therefore, to fulfill this research gap, an attempt has been made in the present study for the artificial aging of the apple tea wine using different wood chips and to study their effect on the physico-chemical, sensory and antimicrobial properties. 


\section{MATERIAL AND METHODS}

\section{Material}

Apple fruits (Golden variety), apple juice concentrate (Himachal Pradesh Horticultural Produce Marketing and Processing Corporation Ltd.), CTC (crush, tear, curl) tea were procured from the local market of Solan (Himachal Pradesh, India). Yeast strain Saccharomyces cerevisiae var. ellipsoideus, (UCD 595) was procured from the Indian Institute of Horticulture Research, Bangalore (Karnataka, India), and was used for the production of the starter culture using apple juice as a base [8]. The crude pectinesterase used was procured from Triton Chemical, Mysore (India) and was used at a concentration of $0.5 \%$. Woods of different trees viz.Quercus spp., Bombax spp. and Acacia spp. were collected from the Forest area of University (Dr. YSP UHF Solan HP India) field for the different treatments of apple tea wine. Chips were made of $5 \times 2 \mathrm{~cm}$ (I $\times$ b) and $0.5 \mathrm{~cm}$ thickness and were oven-dried at $65^{\circ} \mathrm{C}$, till the constant weight was achieved [15].

\section{Experimental}

Apple tea wine was prepared using the standard method as standardized by Kumar and coathors [7] i.e.infusion of tea leaves was prepared by boiling the $4 \mathrm{~g}$ tea per $100 \mathrm{~mL}$ of the apple juice for 3 minutes at $100{ }^{\circ} \mathrm{C}$ and sieved. The TSS (Total Soluble Solids) of these infusions was raised to $20^{\circ} \mathrm{B}$ using apple juice concentrate as a source of sugar. After amelioration, diammonium hydrogen phosphorus followed by addition of sulphur dioxide (100 ppm) in the form of KMS (Potassium metabisulfite) to kill the wild microorganisms and $0.5 \%$ pectinesterase for clarification. After 2 hours, must was inoculated with $5 \%$ of $24 \mathrm{~h}$ old incola (Saccharomyces cerevisiae var. ellipsoideus) having $10^{6} \mathrm{cells} / \mathrm{mL}$ and kept for fermentation at room temperature $\left(24 \pm 2^{\circ} \mathrm{C}\right)$. When a stable TSS was reached, the fermentation was considered complete. Airlocks were fitted in the mouth of carboys near the end of fermentation. After completing the fermentation, siphoning was done followed by filling in new carboys. To these carboys, different wood chips i.e. Quercus spp., Bombax spp. and Acacia spp. were added, respectively with a concentration of $2.5 \mathrm{~g} / \mathrm{L}$ [15]. One carboy was kept as control where no wood chips were added. Aging of all treatments was carried out for 6 months. During aging, apple tea wines were analyzed for different physico-chemical, antimicrobial and sensory characteristics at different storage intervals ( 0,3 and 6 months of storage).

\section{Physico-chemical analysis}

The wines at different storage intervals were analysed for different physico-chemical characteristics i.e. TSS, titratable acidity, $\mathrm{pH}$ and sugars as per the standard methods [16]. Ethanol was measured colorimetrically by potassium dichromate method [17]. Volatile acidity was estimated by titration methods as described by Amerine and coauthors [18] and expresses as per cent acetic acid, while the higher alcohols in apple tea wine were estimated by the method given by Guymon and coauthors [19]. Total phenols were measured colourimetrically using gallic acid as a standard [20]. Total amino acids were estimated by the standard procedure as described by Sadasivam and Manickam [21]. Protein content in different wine samples was determined by Lowry's method as described by Sadasivam and Manickam [21]. Total esters were determined colorimetrically as per the method of Liberaty [22] using ethyl acetate as a standard at $510 \mathrm{~nm}$.

Caffeine content was determined by reversed phase-high performance liquid chromatography (RPHPLC, Waters India), equipped with UV Detector 2489, Autosampler 2707 and Pump 515 on a C18 column $(250 \times 4.6 \mathrm{~mm})$. After maintaining the column temperature at $25^{\circ} \mathrm{C}$, a $10 \mu \mathrm{L}$ filtered sample was loaded in HPLC through an automatic injector along with the mobile phase i.e. water, acetic acid, methanol $(79.9,0.1$ and 20) at a flow rate of $1 \mathrm{~mL} / \mathrm{min}$. A calibration curve of peak areas versus concentration of the standard caffeine was plotted and the caffeine level of various samples was calculated using the regression equation of the best line of fit [7].

Antioxidant activity (free radical scavenging activity) was measured as per the method of Brand-Williams and coauthors [23] using DPPH (2, 2-diphenyl-1-picrylhydrazyl). The sample $(0.1 \mathrm{~mL})$ was added to $3.9 \mathrm{~mL}$ of DPPH $\left(6 \times 10^{-5} \mathrm{~mol} / \mathrm{L}\right)$ in methanol and incubated for 30 minutes at room temperature. The absorbance was measured at $515 \mathrm{~nm}$. DPPH solution was used as a control and only methanol was used as blank. The per cent inhibition of DPPH was calculated according to the Equation 1.

$$
\text { Antioxidant activity (\%) } \quad=\frac{\text { Absorbance of blank }- \text { Absorbance of sample }}{\text { Absorbance of blank }} \times 100
$$


Antimicrobial activity of different apple tea wines against all the test microorganisms i.e. Escherichia coli (IGMC), Enterococcus faecalis (MTCC 2729), Listeria monocytogenes (MTCC 839), Staphylococcus aureus (MRSA 252) and Bacillus cereus (CRI) was detected by Well diffusion method under aerobic conditions [24].

\section{Sensory analysis}

Sensory analysis of different apple tea wines was conducted by 10 semi-trained panel of judges (The panels include the technical people who were having the knowledge of the different attributes of wine. They were capable for sensory analysis as per the prior instructions given.), using composite scoring as described by Amerine and coauthors [18]. The pane includes eight men and two women, having the age range from 24-41 years. Prior to sensory analysis, the respective judges were got familiarized in the training session with different treatments and the composite scale. The discussion was allowed only in the familiarizing session. The judges were asked to rinse their mouth before or in between testing of the given sample and evaluate them for various quality attributes, viz. colour and appearance, aroma and taste, flavour, bitterness, astringency and overall impression, and to award score depending upon their respective intensity. Evaluations were carried out in the isolated booths at room temperature $\left(25 \pm 2{ }^{\circ} \mathrm{C}\right)$. The wines were served in tulip-shaped wine glasses, covered with glass dishes. The mean score of all these attributes was used to draw the overall acceptability of products of various treatments [25].

\section{Statistical analysis}

The data obtained from the physico-chemical attributes of the apple tea wines were subjected to analysis of variance using the completely randomized design (CRD) and the means with critical differences have been reported. Cluster analyses of data were performed to get a comparative comprehensive overview of physicochemical and functional properties of the apple tea wine by using SPSS 16.0 software. The output obtained was plotted as a dendrogram and the interpretation of data was made, accordingly. The statistical analysis of the data obtained from the sensory evaluation of the apple tea wine was done by Randomized Block Design (RBD) as given by Cockrane and Cox [26]. To get the effect of different storage intervals and types of wood chips on physico-chemical and sensory attributes of apple tea wine independently, the means of the respective measures as given in the tables, irrespective of the others.

\section{RESULTS AND DISCUSSION}

\section{Effect of different storage intervals on the physico-chemical attributes of apple tea wine}

The maturation of apple tea wine significantly affected all the physico-chemical attributes of apple tea wine except total sugars, volatile acidity and antioxidant activity (Table 1). With advancement in the storage duration, an increase in reducing sugars, $\mathrm{pH}$, higher alcohol, protein, amino acid and total sugars was observed, whereas, a decrease in TSS, titratable acidity, total phenols, and caffeine can be easily seen (Figure 1). 


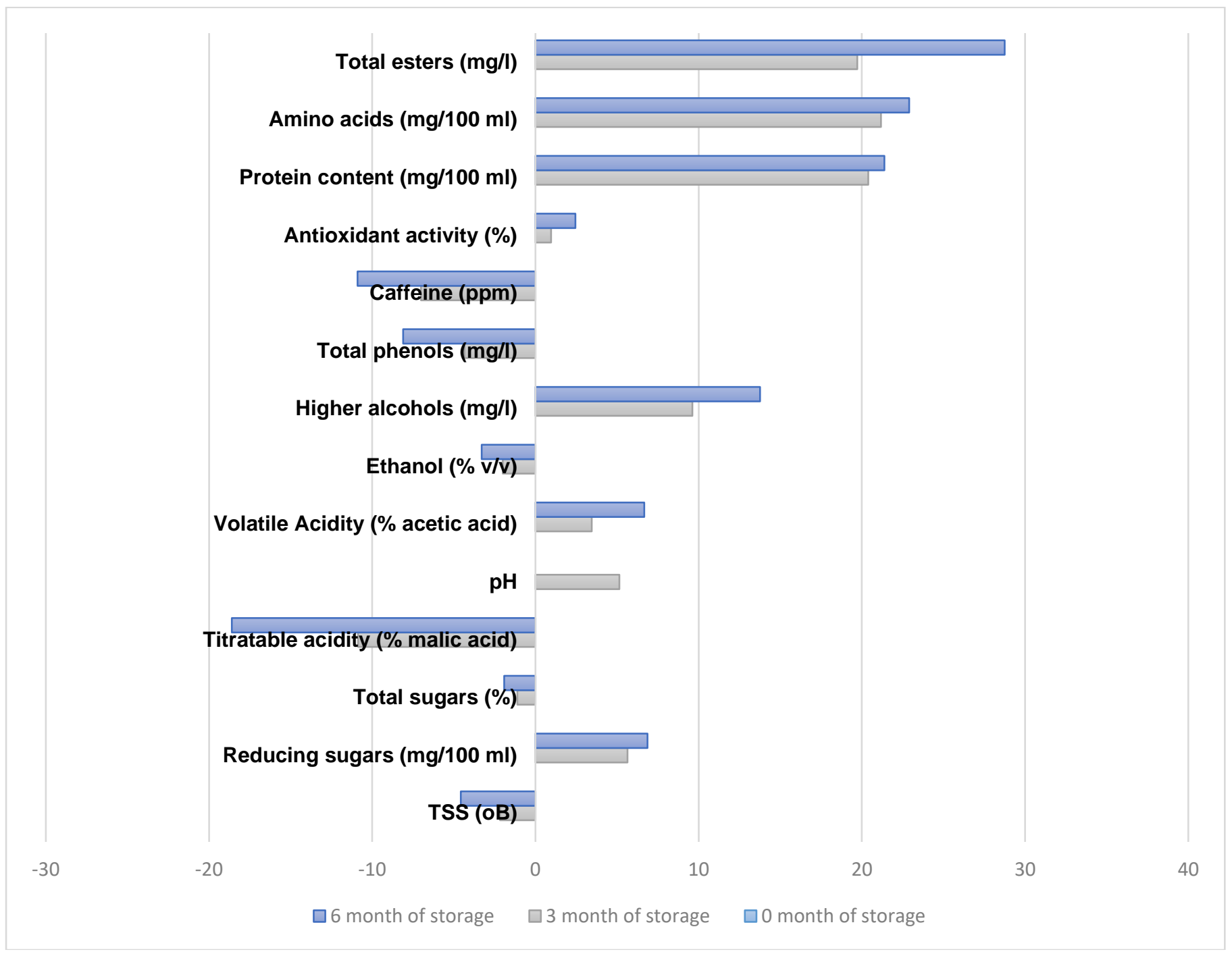

Figure 1. Effect of storage intervals on physico-chemical attributes of apple tea wine as compared to zero month of storage 
Table 1. Effect of different storage intervals on physico-chemical properties of apple tea wine

\begin{tabular}{|c|c|c|c|c|c|c|c|c|c|c|c|c|c|c|}
\hline $\begin{array}{l}\text { Storage } \\
\text { durations }\end{array}$ & $\begin{array}{l}\text { TSS } \\
\left({ }^{\circ} \mathrm{B}\right)\end{array}$ & $\begin{array}{l}\text { Reducing } \\
\text { sugars } \\
(\mathrm{mg} / 100 \mathrm{ml})\end{array}$ & $\begin{array}{c}\text { Total } \\
\text { sugars } \\
(\%)\end{array}$ & $\begin{array}{c}\text { Titratable } \\
\text { acidity } \\
\text { (\% malic acid) }\end{array}$ & $\mathrm{pH}$ & $\begin{array}{c}\text { Volatile } \\
\text { Acidity } \\
\text { (\% acetic acid) }\end{array}$ & $\begin{array}{l}\text { Ethanol } \\
(\% \mathrm{v} / \mathrm{v})\end{array}$ & $\begin{array}{l}\text { Higher } \\
\text { alcohols } \\
(\mathrm{mg} / \mathrm{l})\end{array}$ & $\begin{array}{c}\text { Total } \\
\text { phenols } \\
(\mathrm{mg} / \mathrm{l})\end{array}$ & $\begin{array}{c}\text { Caffeine } \\
\text { (ppm) }\end{array}$ & $\begin{array}{l}\text { Antioxidant } \\
\text { activity (\%) }\end{array}$ & $\begin{array}{c}\text { Protein } \\
\text { content } \\
(\mathrm{mg} / 100 \mathrm{ml})\end{array}$ & $\begin{array}{c}\text { Amino } \\
\text { acids } \\
(\mathrm{mg} / 100 \mathrm{ml})\end{array}$ & $\begin{array}{l}\text { Total } \\
\text { esters } \\
\text { ( } \mathrm{mg} / \mathrm{l})\end{array}$ \\
\hline 0 month & 8 & 502 & $\begin{array}{c}0.63 \\
8\end{array}$ & 1.02 & 3.69 & 0.028 & 8.15 & 94 & 480 & 824 & 79.71 & 1015 & 633 & 114 \\
\hline 3 month & 7.83 & 532 & $\begin{array}{c}0.63 \\
1\end{array}$ & 0.92 & 3.89 & 0.029 & 7.99 & 104 & 460 & 770 & 80.48 & 1275 & 803 & 142 \\
\hline 6 month & 7.65 & 539 & $\begin{array}{c}0.62 \\
6\end{array}$ & 0.86 & 3.69 & 0.03 & 7.89 & 109 & 444 & 743 & 81.71 & 1291 & 821 & 160 \\
\hline$C D_{(P \leq 0.05)}$ & 0.17 & 8 & NS & 0.02 & 0.08 & NS & 0.10 & 2 & 17 & 30 & NS & 82 & 18 & 7 \\
\hline
\end{tabular}


A decrease in TSS during maturation (Table 1) might be due to the precipitation of soluble solids during the interaction of various components. With the advancement of the maturation, a significant increase in the reducing sugars was observed (Table 1) which is apparently the result of hydrolysis of non-reducing sugar into reducing sugar during maturation [18]. It is significant from taste and quality point of view of wine and is one of the desirable effects of maturation of wine. Whereas, the effect of the maturation was non-significant on the total sugars content of apple tea wine (Table 1), which was neither expected also. Precipitation of different acids in terms of their respective salts might be the reason for the decrease in the titratable acidity during the maturation [18] as it is desirable in wines from more acidic fruits during maturation as it increases the palatability of wine. However, no relation was observed among $\mathrm{pH}$ value and titratable acidity of apple tea wine (Table 1) which might be due to the protein contents of apple tea wine which are known to have buffering capacity thus, not reflecting the changes in the acidity in their respective pH values [4]. The legal limits for volatile acidity in different wines are 0.12 per cent for red wines and 0.11 per cent for other wines [18]. From this point of view, wines of all the storage intervals fell within the range and are desirable. The increase in volatile acidity during maturation of apple tea wine (Table 1) might be due to oxidation of wine phenolics to yield peroxide, which in turn oxidizes ethanol to acetaldehyde and subsequently to acetic acid [27].

A decrease in ethanol content during maturation (Table 1) is apparently the result of the interaction between alcohols and acids to form esters $[18,28]$. It is desirable as total ester formation results in higher fruity flavour in the wine. A significant increase in higher alcohols was observed during the maturation of apple tea wine (Table 1). The quantity of higher alcohols, irrespective of treatment, in general, is quite low than the threshold value of $420 \mathrm{mg} / \mathrm{l}$ [18], above which these alcohol produce hang over [29]. Since in apple tea wine fermentation nitrogen source was added, therefore, the level of higher alcohols was curtailed to a significantly lower level, which is quite desirable. Results indicated that during maturation, a significant decrease in total phenols or tannins took place (Table 1) which might be due to the degradation, condensation and polymerization, and subsequent precipitation of the polyphenolic compounds [30] responsible for improving the palatability of wine. These results were in line with the findings of Jayabalan and coauthors [31], who reported that storage intervals influenced the stability of polyphenols. On another hand, oxidation and precipitation of the tannins with proteins might be the cause of their decrease during the maturation of wine [28]. The highest caffeine was observed in apple tea wine at 0 months of storage and it reduced significantly up to $6^{\text {th }}$ month of storage (Table 1). Results of the current study are in line with the findings of Jayabalan and coauthors [31] who reported that caffeine contents of the Kombucha tea decreased up to 60 days of storage.

There was non-significant difference among the different storage intervals on the antioxidant activity of apple tea wine (Table 1). The results of the current study are contrary to the findings of Jayabalan and coauthors [31], who reported that free radical scavenging properties of Kombucha tea also linearly decreased during the storage period. With the advancement of the maturation period from 0 to 6 months, an increase in protein content and amino acid content was observed (Table 1). This might be due to yeast autolysis responsible for the release of proteins, peptides and amino acids by the action of proteases [32], and is considered to have an important role in producing aroma and flavour. Total esters concentration significantly increased with the advancement of the maturation time (Table 1) which is attributed to the phenomenon of aging [18]. Oxidation of ethanol into acetic acid and their interaction and the subsequent increase in the ester content of wine during maturation might have contributed to the increase of total esters [33]. A similar increase in total esters was observed by Joshi and Shah [15] in peach wine.

\section{Effect of different wood chips on the physico-chemical attributes of apple tea wine}

The addition of different wood chips exerted a significant effect on titratable acidity, ethanol, higher alcohol, total phenols, and amino acids, whereas, on the other attributes under study, the effect was nonsignificant (Table 2). The per cent increase or decrease as compared to the control (without wood chips) is given in Figure 2. 


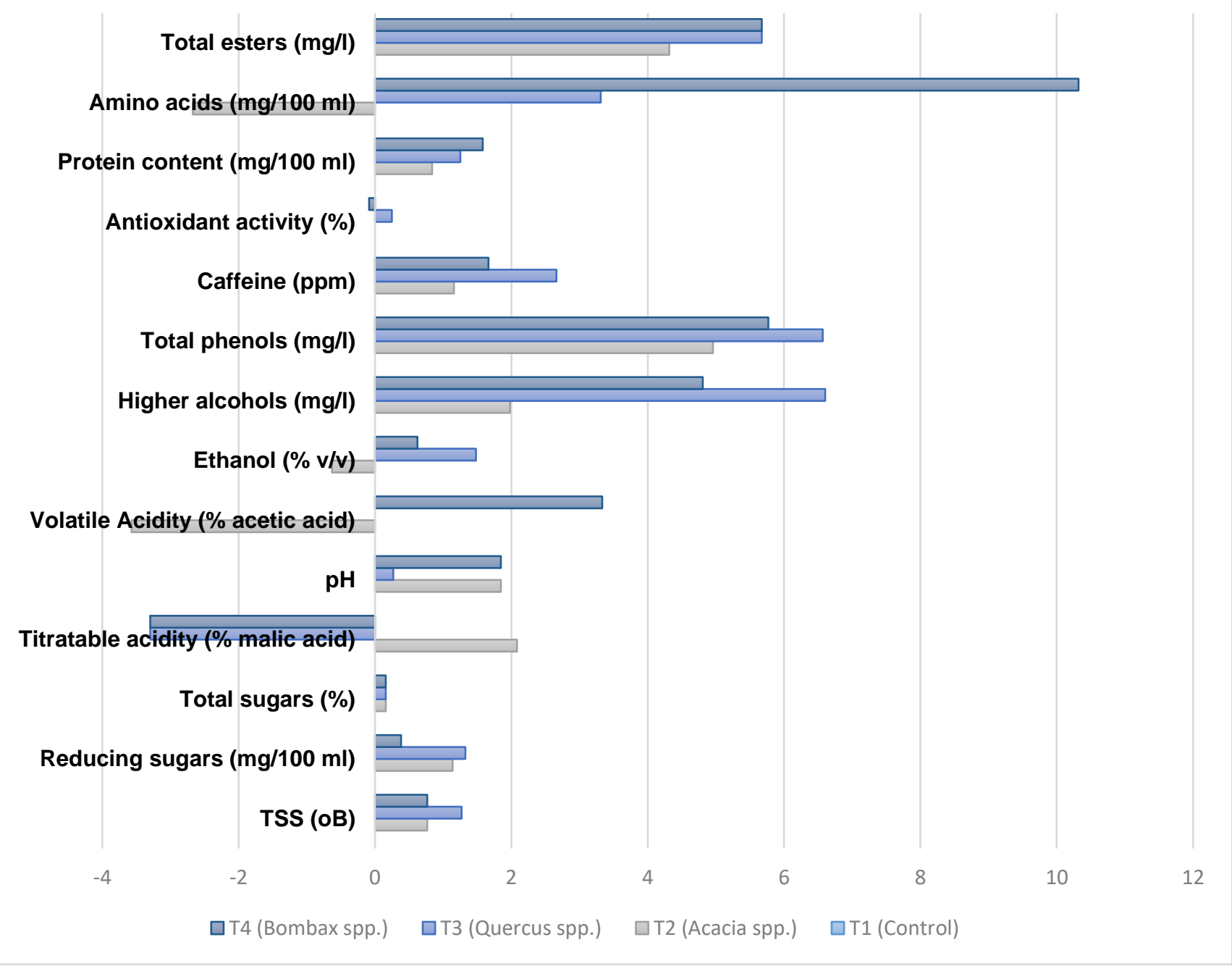

Figure 2. Impact of different wood chips on physico-chemical attributes of apple tea wine as compared to control during storage 
Table 2. Effect of different types of wood chips on physico-chemical properties of apple tea wine

\begin{tabular}{|c|c|c|c|c|c|c|c|c|c|c|c|c|c|c|}
\hline $\begin{array}{l}\text { Wood chips } \\
\text { treatment }\end{array}$ & TSS $\left({ }^{\circ} \mathrm{B}\right)$ & $\begin{array}{c}\text { Reducing } \\
\text { sugars } \\
\text { (mg/100 ml) }\end{array}$ & $\begin{array}{c}\text { Total } \\
\text { sugars } \\
(\%)\end{array}$ & $\begin{array}{l}\text { Titratable } \\
\text { acidity } \\
\text { (\% malic } \\
\text { acid) }\end{array}$ & $\mathrm{pH}$ & $\begin{array}{l}\text { Volatile } \\
\text { Acidity } \\
\text { (\% acetic } \\
\text { acid) }\end{array}$ & $\begin{array}{l}\text { Ethanol } \\
\text { (\% v/v) }\end{array}$ & $\begin{array}{l}\text { Higher } \\
\text { alcohols } \\
(\mathrm{mg} / \mathrm{l})\end{array}$ & $\begin{array}{c}\begin{array}{c}\text { Total } \\
\text { phenols } \\
\text { (mg/l) }\end{array}\end{array}$ & $\begin{array}{c}\text { Caffeine } \\
(\mathrm{ppm})\end{array}$ & $\begin{array}{l}\text { Antioxidant } \\
\text { activity (\%) }\end{array}$ & $\begin{array}{c}\text { Protein } \\
\text { content } \\
(\mathrm{mg} / 100 \mathrm{ml})\end{array}$ & $\begin{array}{c}\text { Amino } \\
\text { acids } \\
(\mathrm{mg} / 100 \mathrm{ml})\end{array}$ & $\begin{array}{l}\text { Total } \\
\text { esters } \\
\text { ( } \mathrm{mg} / \mathrm{l})\end{array}$ \\
\hline $\mathrm{T}_{1}$ (Control) & 7.77 & 521 & 0.631 & 0.94 & 3.72 & 0.029 & 7.98 & 99 & 441 & 768 & 80.60 & 1183 & 730 & 133 \\
\hline $\mathrm{T}_{2}$ (Acacia spp.) & 7.83 & 527 & 0.632 & 0.96 & 3.79 & 0.028 & 7.93 & 101 & 464 & 777 & 80.60 & 1193 & 711 & 139 \\
\hline $\mathrm{T}_{3}$ (Quercus spp.) & 7.87 & 528 & 0.632 & 0.91 & 3.73 & 0.029 & 8.10 & 106 & 472 & 789 & 80.80 & 1198 & 755 & 141 \\
\hline $\mathrm{T}_{4}$ (Bombax spp.) & 7.83 & 523 & 0.632 & 0.91 & 3.79 & 0.030 & 8.03 & 104 & 468 & 781 & 80.53 & 1202 & 814 & 141 \\
\hline$C D_{(P \leq 0.05)}$ & NS & NS & NS & 0.03 & NS & NS & 0.12 & 3 & 19 & NS & NS & NS & 20 & NS \\
\hline
\end{tabular}

NS: Not significant 
The effect of wood chips on the titratable acidity was significant especially in the wine treated with Acacia spp. wood chips (Table 2) which might be probably due to the dissolution of fixed acids [34] and volatile acids [35] from the wood chips. However, the difference in the extraction rate of the initial concentration of acid in the wood chips might be due to the different rate of solubilization by the liquid penetrating to the chips, followed by a different rate of diffusion from inner to outer; and the outer part to liquid i.e. wine [36]. Wood treated wines had more ethanol content than the control wine (Table 2), which might have occurred due to loss of water by evaporation and soaking of wood chips [18,34]. Between wood chips, the difference for higher alcohol could be attributed to the hydrolysis of various wooden components during maturation which might have altered the higher alcohols content. Further, the increase in higher alcohols may be the result of transamination of amino acid, decarboxylation, and reduction of particular ketoacids [37].

The higher phenol contents in the wood treated wines as compared to control (Table 2) might be due to the extraction of more phenolic compounds from wood during the maturation period [15,38-39]. Although, the difference among the woodchips was non-significant but the slight difference might be due to the different rates of diffusion of the phenolic [36]. Higher amount of the amino acid content was observed in apple tea wine treated with Bombax spp. wood chips followed by apple tea wine treated with Quercus spp. wood chips (Table 2). The differences might be due to the respective initial composition of the woodchips [40].

\section{Antimicrobial activity}

With the advancement of maturation period from 0 to 6 month, a decrease in antimicrobial activity was observed, which might be due to decrease in titratable acidity, total phenolics (Figure 3) which play in an important role in antimicrobial activity, irrespective of the type of indicator microbes [4]. Phenolic compounds may affect the growth and metabolism of bacteria and have an activating or inhibiting effect on microbial growth depending upon composition and concentration [41]. The inhibitory effect of phenolic compounds could be due to their adsorption to cell membranes, interaction with enzymes, substrate and metal ion deprivation [41-42]. Titratable acidity (citric acid and malic acid) contributes to $\mathrm{pH}$ reduction, which depresses the internal $\mathrm{pH}$ of bacteria by ionizing the un-dissociated acid molecules, therefore altering the permeability of microbial membrane by disrupting their substrate transport [43-44].

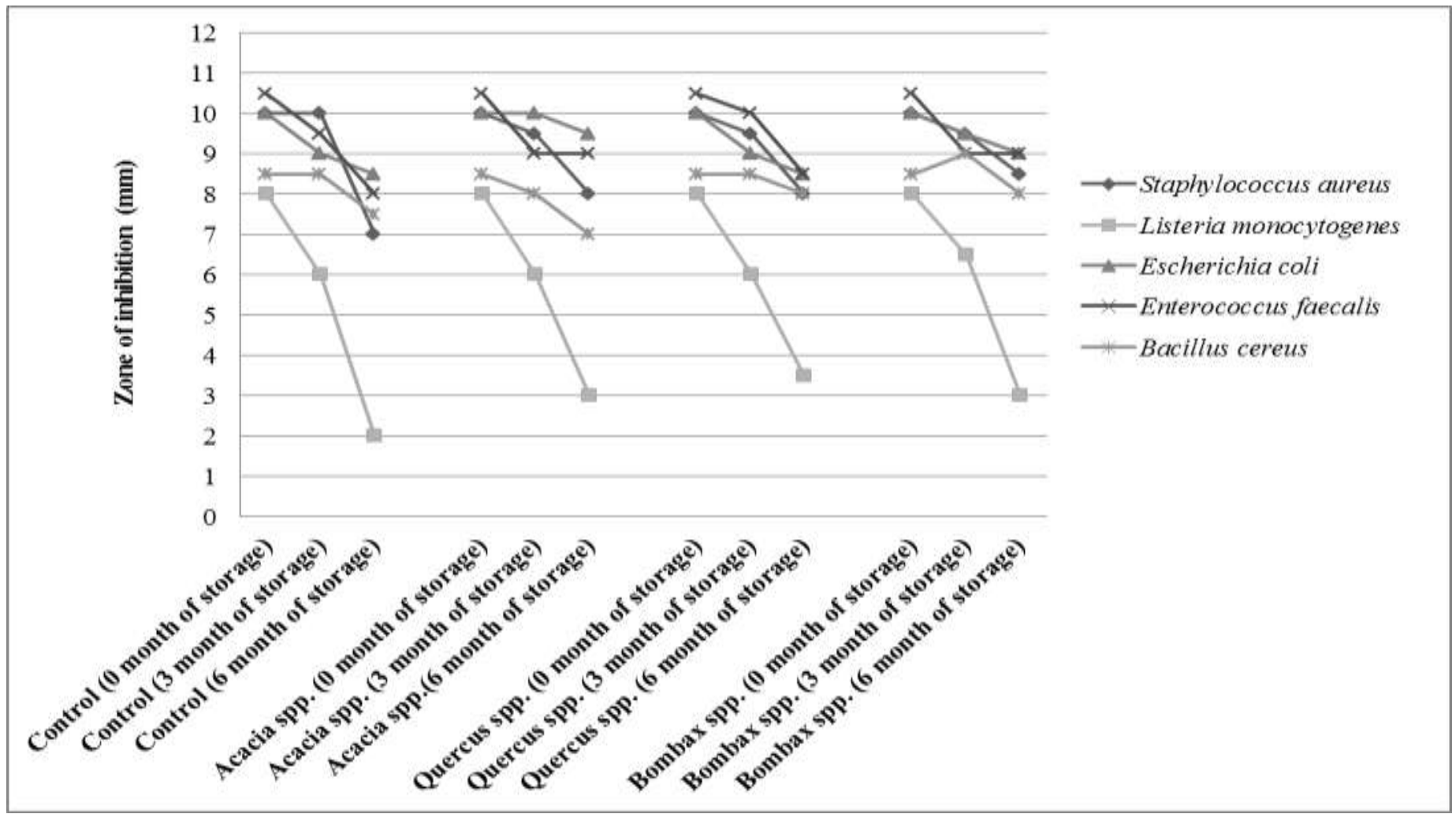

Figure 3. Effect of different wood chips and storage duration on the antimicrobial activity (zone of inhibition; $\mathrm{mm}$ ) of apple tea wine 


\section{Cluster analysis of the different apple tea wines matured with different wood chips}

To get an overview of the effect of different storage duration and wood chips on the physico-chemical attributes of apple tea wine, overall data were analyzed using rescaled distance cluster analysis (Figure 4). It is evident from the figure that major clustering was on the basis of storage duration rather than the wood chips where 0 months of storage grouped in one group than the other treatments indicating that maturation brought a significant change in apple tea wine. It was further observed that further clustering was based on wood chips up to some extent.

\section{Rescaled Distance Cluster Combine}

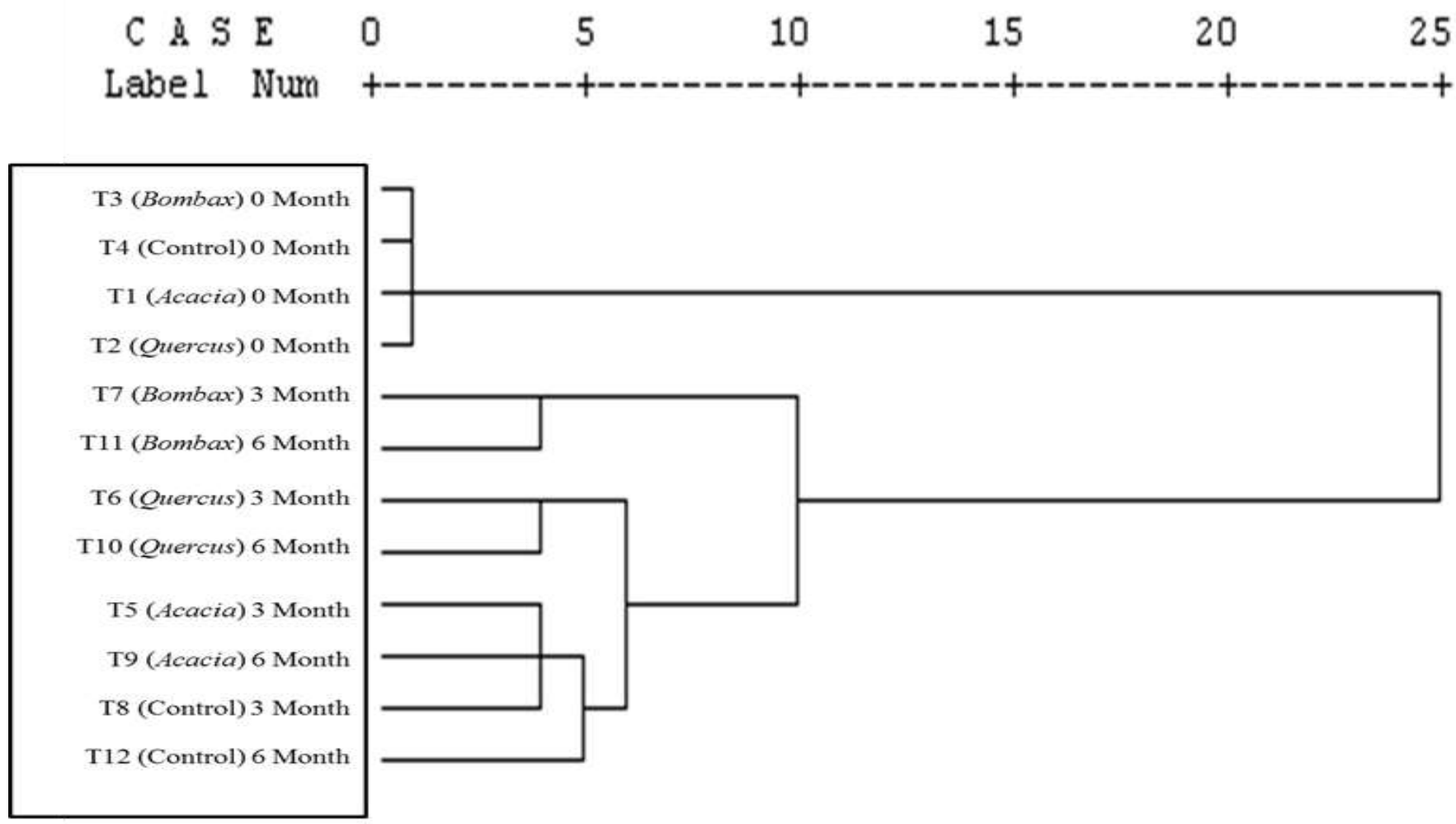

Figure 4. Dendrogram of different treatments of apple tea wine matured with different wood chips using various physicochemical characteristics analysed based on rescaled distance

\section{Sensory evaluation of 6 months matured wine}

The composite scoring test was carried out for the sensory evaluation of 6 month matured apple tea wine. Table 3 summarizes the results of composite scoring of 6 months matured apple tea wine with different wood chips. On the basis of rating, apple tea wines matured with different wood chips after 6 months of storage fell in the 'superior' category; whereas, apple tea wine matured without wood chips after 6 months of storage fell in the 'standard' category. Out of three wood chips used, Quercus spp. treated wine was more preferred by the judges. Similar results have been reported for the Quercus spp. treated peach wine [15]. Better quality of Quercus spp. wood chips treated wine could be correlated with the process of extraction of phenolic substances, which are known to improve the astringency and colour of wines [45]. 
Table 3. Effect of different wood chips treatments on sensory characteristics of apple tea wine

\begin{tabular}{|c|c|c|c|c|c|c|c|c|c|c|c|c|}
\hline $\begin{array}{l}\text { Different wood chips } \\
\text { treatments }\end{array}$ & Appearance & Color & Aroma & $\begin{array}{l}\text { Volatile } \\
\text { acidity }\end{array}$ & $\begin{array}{c}\text { Total } \\
\text { acidity }\end{array}$ & Sweetness & Body & Flavour & Bitterness & Astringency & $\begin{array}{c}\text { Overall } \\
\text { impression }\end{array}$ & Total \\
\hline $\begin{array}{c}\text { Max. Score } \\
\mathrm{T}_{1} \text { (Acacia spp.) }\end{array}$ & $\begin{array}{c}2 \\
1.68\end{array}$ & $\begin{array}{c}2 \\
1.66\end{array}$ & $\begin{array}{c}4 \\
3.54\end{array}$ & $\begin{array}{c}2 \\
1.59\end{array}$ & $\begin{array}{c}2 \\
1.56\end{array}$ & $\begin{array}{c}1 \\
0.68\end{array}$ & $\begin{array}{c}1 \\
0.86\end{array}$ & $\begin{array}{c}2 \\
1.81\end{array}$ & $\begin{array}{c}1 \\
0.77\end{array}$ & $\begin{array}{c}1 \\
0.68\end{array}$ & $\begin{array}{c}2 \\
1.71\end{array}$ & $\begin{array}{c}20 \\
16.54\end{array}$ \\
\hline $\mathrm{T}_{2}$ (Quercus spp.) & 1.79 & 1.80 & 3.68 & 1.51 & 1.56 & 0.72 & 0.84 & 1.84 & 0.79 & 0.67 & 1.75 & 16.95 \\
\hline $\mathrm{T}_{3}$ (Bombax spp.) & 1.72 & 1.69 & 3.63 & 1.52 & 1.56 & 0.63 & 0.79 & 1.87 & 0.76 & 0.70 & 1.78 & 16.65 \\
\hline $\mathrm{T}_{4}$ (Control) & 1.62 & 1.64 & 3.40 & 1.51 & 1.49 & 0.61 & 0.76 & 1.79 & 0.75 & 0.70 & 1.73 & 16.00 \\
\hline$C D(P \leq 0.05)$ & 0.08 & NS & 0.08 & NS & NS & 0.07 & NS & NS & NS & NS & NS & 0.25 \\
\hline
\end{tabular}

Ratings: Superior (17-20); standard (13-16); below standard (9-12); unacceptable or spoiled (1-8) 


\section{CONCLUSION}

An appraisal of the results and cluster analysis obtained from the current study showed that storage intervals exerted more effect on the physico-chemical and antimicrobial properties of the apple tea wine rather than the wood chips. Wood chips had a significant effect on the sensory quality of the apple tea wine. Based on the results, it is concluded that apple tea wine matured with Quercus spp. wood chips for 6 months were the best with improved physico-chemical and sensory attributes.

Acknowledgments: The authors want to thanks Dr. Y S Parmar UHF Nauni, Solan (HP) India for providing infrastructure facilities and providing financial support.

Conflicts of Interest: "The authors declare no conflict of interest."

\section{REFERENCES}

1. Joshi VK, Sharma S. Importance, nutritive value and medicinal contribution of wines. Bev Food World. 2004;31(2):41-5.

2. Stockley SC. Therapeutic value of wine: A clinical and scientific perspective.In: Joshi VK, editor. Handbook of enology: Principles, practices and recent innovations.New Delhi: Asia Tech Publishers, Inc.; 2011. p. 146-208.

3. Joshi VK, Thakur NS, Bhat A, Garg C. Wine and brandy: A perspective. In: Joshi VK, editor. Handbook of enology: Principles, practices and recent innovations. New Delhi: Asia Tech Publishers, Inc.; 2011. p. 3-45.

4. Kumar V, Joshi VK, Vyas G, Thakur NS, Sharma N. Process optimization for the preparation of apple tea wine with analysis of its sensory and physico-chemical characteristics and antimicrobial activity against food-borne pathogens. Nutrafoods.2016; 15: 111-121.

5. Gortzi O, Metaxa X, Mantanis G, Lalas S. Effect of artificial ageing using different wood chips on the antioxidant activity, resveratrol and catechin concentration, sensory properties and colour of two Greek red wines. Food Chem. 2013;141(3):2887-95.

6. Laplace JM, Jacquet A, Travers I, Simon JP, Auffray Y. Incidence of land and physico-chemical composition of apples on the qualitative and quantitative development of microbial flora during cider fermentations. J. Inst. Brew. $2001 ; 107(4): 227-34$.

7. Kumar V, Joshi VK, Vyas G, Tanwar B. Effect of different types of fermentation (inoculated and natural fermentation) on the functional properties of apple tea wine. Res J Pharm Biol. Chem Sci. 2015; 6: 847-54.

8. Joshi VK, Kumar V. Influence of different sugar sources, nitrogen sources and inocula on the quality characteristics of apple tea wine. J Inst Brew. 2017; 123(2): 268-76.

9. Sánchez-Iglesias M, González-Sanjosé ML, Pérez-Magariño S, Ortega-Heras M, González-Huerta C. Effect of micro-oxygenation and wood type on the phenolic composition and color of an aged red wine. J. Agr. Food Chem.30;57(24):11498-509.

10. Madrera RR, Valles BS, García YD, del Valle Argüelles P, Lobo AP. Alternative woods for aging distillates-an insight into their phenolic profiles and antioxidant activities. Food Sci. Biotechnol, 2010; 19(4):1129-34.

11. Singleton VL, Esau P. Phenolic substances in grapes and wine, and their significance. New York: Advances in food research.Academic Press; 1969.

12. Bozalongo R, Carrillo JD, Torroba MÁ, Tena MT. Analysis of French and American oak chips with different toasting degrees by headspace solid-phase microextraction-gas chromatography-mass spectrometry. $\mathrm{J}$ Chromatogr $\mathrm{A}$. $2007 ; 1173(1-2): 10-7$.

13. Afonso VG. Sensory descriptive analysis of red wines undergoing malolactic fermentation with oak chips. J Food. Sci. 2003;68(3):1075-9.

14. Joshi VK, Mahajan BV, Sharma RK.Treatment of wines with wood-chip effect on some physico-chemical and sensory qualities.J. Tree Sci. 1994;13(1):27.

15. Joshi VK, Shah PK. Effect of wood treatment on chemical and sensory quality of peach wine during ageing. Acta Aliment Hung. 1998;27(4):307-18.

16. Joshi VK and Sandhu DK. Influence of ethanol concentration, addition of spices extract, and level of sweetness on physico-chemical characteristics and sensory quality of apple vermouth. Braz Arch Biol Technol. 2000; 43(5): 53745.

17. Caputi AJ, Veda M and Brown J. Spectrophotometer determination of ethanol in wine. Am J EnolVitic. 1968; 26: 201-207.

18. Amerine MA, Berg HW, Kunkee RE, Ough CS, Singleton VL, Webb AD. The Technology of Wine Making, $4^{\text {th }}$ ed. Westport, CT: Avi Publishing; 1980.

19. Guymon JF, Ingraham JL, Crowell EA. Influence of aeration upon the formation of higher alcohols by yeasts. Am J Enol Vitic. 1961; 12(2): 60-6.

20. Singleton VL, Rossi JA.Colorimetry of total phenolics with phosphomolybdic-phosphotungstic acid reagents. Am. J. Enol. Vitic. 1965;16(3):144-58. 
21. Sadasivam S,Manickam A. Biochemical methods. New Delhi, India: New Age International Ltd.; 1991

22. Liberaty V. Ester determination and their applications to wine, MSc Thesis. Davis, CA.: University of California. 1961.

23. Brand-Williams W, Cuvelier ME, Berset CL. Use of a free radical method to evaluate antioxidant activity. Lebensm.Wiss. Technol. 1995;28(1):25-30.

24. Schillinger U, Lücke FK. Antibacterial activity of Lactobacillus sake isolated from meat. Appl. Environ. Microb.1989; 55(8):1901-6.

25. Joshi VK, Sharma SK, GoyalRK and Thakur NS. Effect of method of secondary fermentation and type of base wine on physico-chemical and sensory qualities of sparkling plum wine.Braz Arch Biol Technol. 1999; 42(3): 315-22.

26. Cochran, WG, Cox GM. Experimental designs. 14th ed. Bombay: Asia Publishing House. 1963.

27. Wildenradt HL, Singleton VL. The production of aldehydes as a result of oxidation of polyphenolic compounds and its relation to wine aging. Am. J. Enol. Vitic. 1974; 25(2):119-26.

28. Zoecklein BW, FugelsangKC, GumpBH and Nury FS.Wine analysis and production.New york: Chapman Hall, New York; 1995.

29. Fowles G. The complete home wine-maker.New Sci.1989;123(1680):38-43.

30. Somers TC. Assessment of phenolic components in viticulture and oenology.In: Lee T. editor.Proceedings of Sixth Australian Wine Industry Technical Conference. Australia: Australian Industrial Publishers, Australia.;1987.p. 257261.

31. Jayabalan R, Malbaša RV, Lončar ES, Vitas JS, Sathishkumar M.A review on kombucha tea-microbiology, composition, fermentation, beneficial effects, toxicity, and tea fungus.Compr Rev Food Sci Food Saf.2014; 13(4): 538-50.

32. Bhushan S, Sharma, S. Maturation of Wines and Brandies. In: Joshi VK, editor. Handbook of enology: Principles, practices and recent innovations. New Delhi: Asia Tech Publishers, Inc.; 2011. p. 861-900.

33. Castino M, Cravero MC, Ponzetto L. Some considerations on the use of barrels for ageing of red wines. Enotecnico.1994; 49-53.

34. Shah PK, Joshi VK. Effect of Different Sugar Sources and Wood Chips on the Quality of Peach Brandy. J. Sci. Ind. Res. 1999;58 (6): 995-1004.

35. Aiken JW, Noble AC. Comparison of the aromas of oak-and glass-aged wines. Am. J. Enol. Vitic. 1984;35(4):1969.

36. Kadim D, Mannheim $\mathrm{CH}$. Kinetics of phenolic extraction during aging of model wine solution and white wine in oak barrels. Am. J. Enol. Vitic. 1999;50(1):33-9.

37. Wondra M, Berovic M. Analyses of aroma components of Chardonnay wine fermented by different yeast strains. Food Tech. Biotechnol. 2001; 39(2):141-8.

38. Quinn MK, Singleton VL. Isolation and identification of ellagitannins from white oak wood and an estimation of their roles in wine.Am. J. Enol. Vitic. 1985; 36(2):148-55.

39. Wilker KL, Gallander JF. Comparison of Seyvalblanc wine aged in barrels and stainless steel tanks with oak chips. Am. J. Enol. Vitic. 1988;39(1):38-43.

40. Özcan T. Total protein and amino acid compositions in the acorns of Turkish Quercus L. taxa.Genet.Resour. Crop Ev. 2006;53(2):419-29.

41. Vaquero, M. R., Alberto, M. R., and De Nadra, M. M. (2007).Antibacterial effect of phenolic compounds from different wines, Food Control. 18(2), 93-101.

42. Vaquero MR, Alberto MR, De Nadra MM. Antibacterial effect of phenolic compounds from different wines. Food Control. 2007;18(2):93-101.

43. Scalbert A. Antimicrobial properties of tannins. Phytochemistry. 1991;30(12):3875-83.

44. Allende A, McEvoy J, Tao Y, Luo Y. Antimicrobial effect of acidified sodium chlorite, sodium chlorite, sodium hypochlorite, and citric acid on Escherichia coli O157: $\mathrm{H} 7$ and natural microflora of fresh-cut cilantro. Food Control .2009; 20(3):230-4.

45. BischofVukušić $S$, FlinčecGrgac $S$, Budimir A, Kalenić S. Cotton textiles modified with citric acid as efficient antibacterial agent for prevention of nosocomial infections. Croat Med J. 2011;52(1):68-75.

46. McRae JM, Schulkin A, Kassara S, Holt HE, Smith PA. Sensory properties of wine tannin fractions: Implications for in-mouth sensory properties. J. Agr. Food Chem. 2013;61(3):719-27.

(C) 2020 by the authors. Submitted for possible open access publication under the terms and conditions of the Creative Commons Attribution (CC BY NC) license (https://creativecommons.org/licenses/by-nc/4.0/). 